
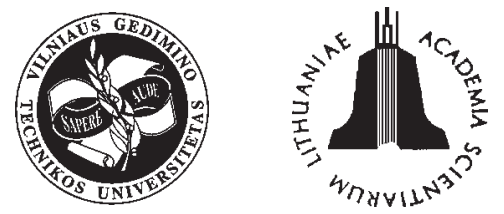

JOURNAL OF CIVIL ENGINEERING AND MANAGEMENT

http:/www.jcem.vgtu.lt

2005, Vol XI, No 3, 185-191

\title{
VIBRATION TRANSMISSION THROUGH JOINTS OF WALLS AND COLUMNS IN FRAMED BUILDINGS
}

\author{
Marius Mickaitis, Vytautas J. Stauskis \\ Dept of Building Structures, Vilnius Gediminas Technical University, Traku g. 1/26, LT-01132 Vilnius, Lithuania \\ E-mail:mickaitis@mail.com; stauskis@ar.vtu.lt
}

Received 20 Apr 2005; accepted 17 June 2005

\begin{abstract}
Constructional practice has shown that structure-borne sound transmission through joints can signally reduce airborne sound insulation in buildings. Vibration transmission coefficient evaluates this reduction in design calculations. In this article sound transmission through joints in framed buildings is investigated. Rooms in framed buildings are shaped by walls and ceilings connected to columns. Several walls could be connected to each column in a building plan. Such joints are modelled like idealised plate-beam-plate junctions. Examining vibration transmission through these junctions, the influence of a column must be estimated. The column will resist forces and moments applied by the connected walls. The aim of the paper is to evaluate how various properties of walls and columns influence the vibration transmission loss at joints of buildings. The results are compared with the results of similar junctions without columns.
\end{abstract}

Keywords: structural acoustics, vibration, structure-borne sound, joints, transmission loss.

\section{Introduction}

Protection from noise is one of the main six EU Construction Product Directive 89/106/EEC requirements, the new building must satisfy. This and other requirements for building protection from noise were transferred to national laws as construction technical regulation, hygienic rules and other laws. Standards for dwelling-house protection from noise created more than 50 years ago in many European countries were complicated. Therefore it was decided to unify the design and measurement procedures of building acoustical properties in the whole Europe. When Lithuania became a member of European Union, the European laws for protection from noise became mandatory.

The performed investigations in many European countries have shown that many buildings, including some new ones built in Lithuania, mismatch the rules of protection from noise. Even these laws are observed, not always the protection from noise would be sufficient, as only minimised general requirements for acoustical comfort are given in the standards.

Building protection from noise is realised in designing, constructing and commissioning stages. Acoustical properties of building are predicted according to series of LST EN 12354 standards [1]. The standard has six parts. The first part describes principle of airborne sound insulation prediction between the rooms. Practice has shown that flanking sound transmission through the junc- tions of buildings frequently is a reason for great decrease of airborne sound insulation. Vibration reduction index $K_{\mathrm{ij}}$ evaluates structure-borne sound transmission in design calculations. Values of index are determined taking into account transmission coefficient $\gamma_{\mathrm{ij}}$ and frequency $f$ according to LST EN 12354-1 [1]:

$$
K_{i j}=-10 \lg \gamma_{i j}+5 \lg \frac{f_{c}}{f_{r e f}},
$$

where $f_{\mathrm{c}}-$ critical frequency $(\mathrm{Hz}), f_{\text {ref }}-$ reference frequency $\left(f_{\text {ref }}=1000 \mathrm{~Hz}\right)$.

Vibration reduction index also evaluates the influence of flanking impact sound transmission in buildings. However, this influence is less than that of structure-borne sound transmission.

In the standard only minor values of vibration reduction index for common junctions in buildings are given. In modern construction more and more non-traditional solutions appear, where joints are asymmetrical, also joints with elastic layers, etc. Therefore designers, wishing to evaluate vibration transmission through the mentioned junctions, could have serious problems because of a lack of necessary data. As there are not many comprehensive survey results of such complicated structural connections, it could only be referred to few surveys performed for determining vibration transmission through joints.

Lack of standards is one of the reasons of this problem. The standard ISO 10848, which determines experi- 
mental investigation of building junctions, has been prepared, but its entering into force date is not clear. Therefore analytical evaluation of various complicated junctions of buildings is important.

The aim of the paper is to evaluate how properties of walls and columns influence the bending wave transmission loss at joints of buildings. The results are compared with the results of similar junctions without columns.

\section{Analytical methods for wave transmission through junctions}

The modelling of structure-borne sound transmission through junctions is an important question in the study of mechanical vibrations of structures. These junctions can influence a change of material or cross-section of the structure. The biggest part of investigations of wave transmission through junctions in buildings investigations is based on semi-infinite, isotropic plate theory. Transmission coefficient $\gamma_{\mathrm{ij}}$ is defined as the ratio of incident power $W_{\text {inc }}$ and transmitted power $W_{\text {tr }}$ of the bending wave field at a junction:

$$
\gamma_{i j}=\frac{W_{t r}}{W_{i n c}}
$$

Transmission coefficients of junction between semiinfinite plates have been calculated by several authors. One of the originators Cremer L. et al [2] investigated bending and longitudinal wave transmission at normal incident for various joints. He also calculated wave transmission for oblique incidence for an $\mathrm{L}$ junction. Kihlman T. [3] analysed bending wave transmission at $X$ junctions at random incidence. His analysis is correct for symmetrical structures but not for $\mathrm{L}$ and $\mathrm{T}$-junctions. Woehle W. et al [4-5] modelled a junction of semi-infinite plates rigidly connected to a beam with no mass. Several authors [6-8] developed improvements of the basic theories. Gibbs B. M. [6] investigated wave type conversion for a various T-junctions. Langley R. S. and Heron K. H. described [7] structure-borne sound transmission through various junctions at random incidence. The plates were either connected through a beam or connected directly forming a rigid line joint. McCollum M. C. and Cuschieri J. M. analysed [8] vibration transmission through $\mathrm{L}$ junction evaluating in-plane waves, shear and rotary inertia effects in the plates. Several studies [9-10] investigated the influence of vibration transmission and wave type conversion in beams. The results of the research can be applied to vibration transmission from beams to plates at normal incidence.

Rooms in framed buildings are shaped by walls and ceilings connected to columns. Several walls could be connected to each column in a building plan. Such joints are modelled like idealised plate-beam-plate junctions. Examining vibration transmission through these junctions, the influence of a column must be estimated.
Junctions of walls and columns in framed buildings have been analysed by several researchers [11-15]. Cremer L. et al [2] calculated the in-line junction, where two plates were connected to a column from opposite sides. The column was modelled as a very thin beam. Later the author extended investigations by including moments applied to a column. These moments were caused by shear forces in the walls at the boundary of the column. Craven P. G. et al [11-12] and Gibbs B. M. et al [13] evaluated the column in various $\mathrm{L}, \mathrm{T}$ and $\mathrm{X}$ joints, where the column resisted forces and moments applied from the connected walls. The mentioned authors have not divided in-plane waves into transverse and longitudinal waves in these studies. It has been done by Steel J. A. [14], who evaluated the influence of frequency on vibration transmission through various junctions with a column with the help of analytical and experimental methods. He discovered that estimating the in-plane waves, the column slightly increase vibration transmission at high frequencies.

In this article the bending wave transmission through junctions of walls and column is evaluated and in-plane waves are neglected. Therefore vibration transmission coefficient is independent of the frequency. Junctions of different form, wall and column properties are investigated. This work extends the further analysis $[15,16]$ of the authors dedicated to vibration transmission through junctions in buildings.

\section{Calculation model of the joint}

\subsection{Bending wave approach}

Bending wave transmission through joints of walls and a column is analysed by modelling joint of semiinfinite plates, rigidly attached to a beam. Plates are assumed to be as acoustically thin and isotropic. The rigid joint configuration considered in this work is shown in Fig 1 .

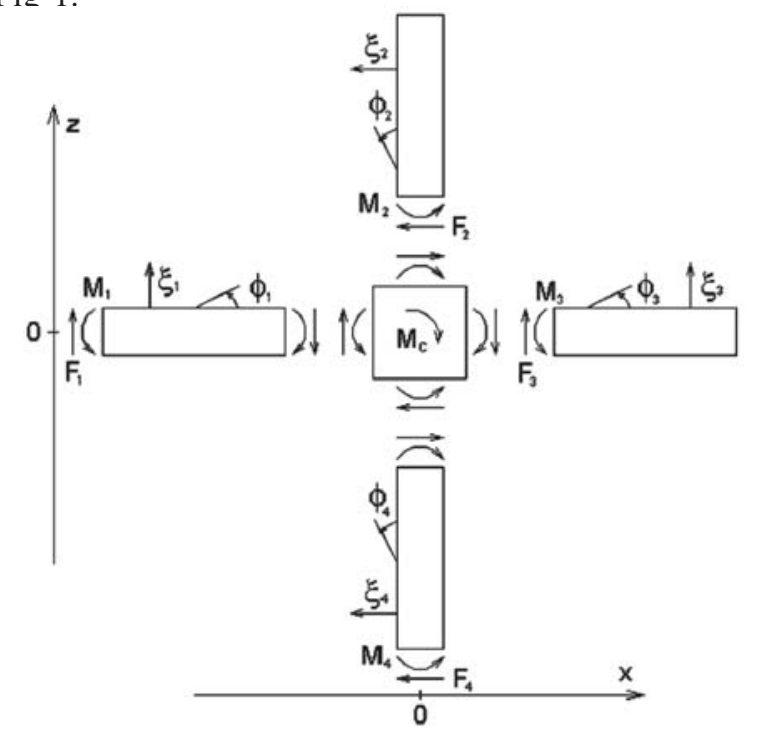

Fig 1. Geometry, displacements and forces of a rigid joint between four plates and a column 
Bending wave incidents on the joint from the boundary of the first plate at an angle $\theta$ and travels in the positive direction of $x$-axis. The wave amplitude is unitary. In this paper the basics of the derivation are given to present important equations necessary for calculating of the vibration transmission coefficients. A full derivation of the bending wave equation is given in standard articles [2]. The number of waves $k_{\mathrm{x}}$ in the direction of $x$-axis is $k \cos \theta$, and number of waves $k_{y}$ in the direction of $y$-axis is $k \sin \theta$. The displacement $\xi$ of this incident wave according to Cremer L. et al [2] will be equal to:

$$
\xi_{\text {inc }}=e^{-i k_{1} \cos \theta x} e^{-i k_{1} \sin \theta y} e^{i w t} .
$$

Bending wave gives the total displacement of the first plate:

$\xi_{1}=\left(e^{-i k_{1} \cos \theta_{1} x}+A_{1} e^{i k_{1} \cos \theta_{1} x}+A_{n 1} e^{k n_{1} x}\right) e^{-i k_{1} \sin \theta_{1} y} e^{i w t}$,

where $A_{\mathrm{i}}, A_{\mathrm{ni}}$ - corresponding amplitudes of travelling and near field waves $(\mathrm{m}), k_{\mathrm{i}}, k_{\mathrm{ni}}$ - corresponding numbers of travelling and near field waves.

$$
k_{i}=w^{1 / 2}\left(\rho_{s} / B\right)^{1 / 4}, \quad k_{n i}=k_{i}\left(1+\sin ^{2} \Theta\right)^{1 / 2},
$$

where $\rho_{\mathrm{S}}$ - surface density $\left(\mathrm{kg} / \mathrm{m}^{2}\right), B$ - bending stiffness per unit width of a plate $(\mathrm{Nm})$.

$$
B=E I=\frac{E h^{3}}{12\left(1-\mu^{2}\right)},
$$

where $E$ - Young's modulus $\left(\mathrm{N} / \mathrm{m}^{2}\right), I-$ moment of inertia of the plate $\left(\mathrm{m}^{3}\right), h$ - cross-sectional height of the plate (h), $\mu$ - Poisson's ratio.

The displacements of all plates $\xi_{\mathrm{i}}$ produced by bending wave are:

$$
\begin{aligned}
& \xi_{2}=\left(A_{2} e^{-i k_{2} \cos \theta_{2} z}+A_{n 2} e^{-k_{n 2} z}\right) e^{-i k_{2} \sin \theta_{2} y} e^{i w t} \\
& \xi_{3}=\left(A_{3} e^{-i k_{3} \cos \theta_{3} x}+A_{n 3} e^{-k_{n 3} x}\right) e^{-i k_{3} \sin \theta_{3} y} e^{i w t} \\
& \xi_{4}=\left(A_{4} e^{i k_{4} \cos \theta_{4} z}+A_{n 4} e^{k_{n 4} z}\right) e^{-i k_{4} \sin \theta_{4} y} e^{i w t}
\end{aligned}
$$

where $k_{1} \sin \theta_{1}=k_{i} \sin \theta_{i}$.

The slope on each plate $\phi_{i}$ is given in terms of the displacement $\xi_{\mathrm{i}}$ on each plate (Fig 1) as:

$\phi_{1}=\frac{\partial \xi_{1}}{\partial x} ; \quad \phi_{2}=\frac{\partial \xi_{2}}{\partial z} ; \quad \phi_{3}=\frac{\partial \xi_{3}}{\partial x} ; \quad \phi_{4}=\frac{\partial \xi_{4}}{\partial z}$.

Bending wave also causes moments $M_{\mathrm{i}}$ on each plate, which can be calculated by the following equation given by Cremer L. et al [2]:

$$
M_{i}=-B_{i}\left(\frac{\partial^{2} \xi_{i}}{\partial x^{2}}+\mu \frac{\partial^{2} \xi_{i}}{\partial z^{2}}\right)
$$

All moments acting to the column from each plate will be resisted by total resisting moment $M_{\mathrm{c}}$. This resisting moment in the column is also given by Cremer L. et al [2]:

$$
M_{c}=-\left(w^{2} \rho_{c} J-G_{c} k_{1}^{2} \sin ^{2} \theta_{1}\right) \frac{\partial \xi_{1}}{\partial x},
$$

where $\rho_{\mathrm{c}}-$ density of column material $\left(\mathrm{kg} / \mathrm{m}^{3}\right) ; J-$ polar moment of inertia of the column $\left(\mathrm{m}^{4}\right), \mathrm{J}=h_{\mathrm{c}}^{4} / 6 ; h_{\mathrm{c}}-$ column width/thickness (m); $G_{\mathrm{c}}-$ torsion stiffness of the column $\left(\mathrm{N} / \mathrm{m}^{2}\right), G_{\mathrm{c}}=\left(E K_{\mathrm{T}}\right) / 2(1+\rho) ; K_{\mathrm{T}}$ - torsion stiffness constant, $K_{\mathrm{T}}=0,14 h_{\mathrm{c}}^{4}$ (for square column).

\subsection{Conditions at the boundary}

Bending wave will act on the boundary of the column from the first plate and will cause the column crosssection deformations. As a result, bending waves generate on the second, third and fourth plate. We assume there are no displacements at the joint. The condition, stating that displacement at the edge where $x=0$ and $z=0$ of the first plate $\xi_{1}$ is equal to zero, simplifies equation (4) to

$$
1+A_{1}+A_{\mathrm{n} 1}=0
$$

Accordingly, from equations (7-9) can be found:

$$
\begin{aligned}
& A_{2}+A_{\mathrm{n} 2}=0, \\
& A_{3}+A_{\mathrm{n} 3}=0, \\
& A_{4}+A_{\mathrm{n} 4}=0 .
\end{aligned}
$$

Moment acting on the first plate will be resisted by the moments acting on the other plates. Only the part of the moment acting on the first plate, which is equal to the moment acting on the third plate will deform the column cross-section. Therefore deformation of the column can be estimated from the moment acting on the third plate. The difference between slopes on first and the third plates is equal to $M_{3} / B_{\mathrm{c}}$ (for the square cross-section column $\left.B_{\mathrm{c}}=E h_{\mathrm{c}}^{2} / 12\right)$.

Next boundary condition can be written as a result, that slope on the first plate is equal to the slope on the third plate estimating the slope difference due to the column deformation

$$
\phi_{1}=\phi_{3}-M_{3} / B_{c} .
$$

The slope on the first plate can be related with the slopes on the second and fourth plate. The difference between slopes on the first and second plates is equal to the half of the difference between slopes on the first and third plates, which is equal to $M_{3} / 2 B_{\mathrm{c}}$. This condition is also valid to the difference between slopes on the first and fourth plates. Therefore, two more boundary conditions can be written as:

$$
\begin{aligned}
& \phi_{1}=\phi_{2}-M_{3} / 2 B_{c}, \\
& \phi_{1}=\phi_{4}-M_{3} / 2 B_{c} .
\end{aligned}
$$

And finally the moments acting at the joint must balance. The moments acting from the plates to the boundary of the column will be resisted by the moment acting in the column:

$$
M_{1}-M_{2}-M_{3}+M_{4}=M_{\mathrm{c}} .
$$


Solving the system of equations (17-20) the unknown amplitudes $A_{2}, A_{3}$ and $A_{4}$ of the bending waves, generated from the joint to the second, third and fourth plates can be calculated.

\subsection{Calculation of the transmission coefficient}

Calculation of the transmission coefficient $\gamma_{1 \mathrm{j}}$ according to Cremer L. et al [2], when the vibration generates from the first joint element towards the other ones, is made according to

$$
\gamma_{1 j}=\frac{\rho_{s j} k_{1} \cos \theta_{j}}{\rho_{s 1} k_{j} \cos \theta_{1}}\left|A_{j}\right|^{2} .
$$

The presented model for the bending wave transmission through the $\mathrm{X}$ joint of walls and the column can be used also for other forms of junctions. For example, calculating the transmission coefficient for in-line, $\mathrm{L}$ or $\mathrm{T}$ joints, corresponding boundary conditions (18) and/or (19) are neglected. Also the non-acting moments $M_{\mathrm{i}}$ in equation (20) are neglected respectively to Fig 1. Generally the transmission coefficient in the literature referred is presented as the transmission loss equal to $-10 \lg \gamma_{\mathrm{ij}}(\mathrm{dB})$.

\section{Numerical results}

According to the described calculation model the bending wave transmission coefficient for various junctions in buildings can be calculated. In-line, L and T-junctions are analysed. Vibration transmission coefficient $\gamma_{\mathrm{ij}}$ is assumed to be frequency independent and was calculated by equations (17-21). For all cases of the joint form the calculations for the column with the following characteristics were performed: $\rho_{\mathrm{c}}=2500 \mathrm{~kg} / \mathrm{m}^{3}$, $\mathrm{E}_{\mathrm{c}}=25 \cdot 10^{9} \mathrm{~N} / \mathrm{m}^{2}$ and $\mu_{c}=0,25$ [17]. Column crosssection was square. The calculations were performed for 0,3-0,5 m height/thickness column in the joint.

Configuration for the in-line joint is shown in Fig 1 neglecting the second and the fourth plates and respectively the non-acting forces and moments. Vibration transmission coefficient $\gamma_{13}$ was calculated by Eqs 17, 20-21. The influence of cross-section height $h_{1} / h_{3}$ alternation on vibration transmission coefficient was investigated. Therefore it was assumed that all plates had been made from silicate bricks with the following characteristics: $\rho=2000 \mathrm{~kg} / \mathrm{m}^{3}, \mathrm{E}=16 \cdot 10^{9} \mathrm{~N} / \mathrm{m}^{2}$ and $\mu=0,2$ [17].

Transmission losses for the in-line joint, where the cross-section height of the first plate alternates from $0,1 \mathrm{~m}$ to $1,0 \mathrm{~m}$ and the cross-section height of the third plate is constant and equal to $0,1 \mathrm{~m}$, are shown in Fig 2. The results in the diagram are compared with the results of similar in-line junction without a column.

When the cross-section height of the first plate is constant and equal to $0,1 \mathrm{~m}$, and the cross-section height of the third plate alternates from $0,1 \mathrm{~m}$ to $1,0 \mathrm{~m}$, the transmission losses are equal to the values of the dia-

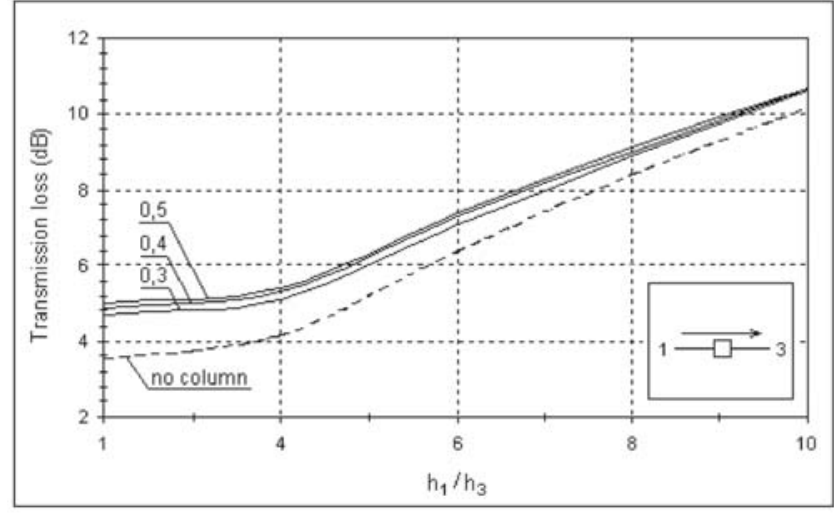

Fig 2. Transmission losses for the in-line joint $\left(\rho_{1}=\rho_{3}=\right.$ $2000 \mathrm{~kg} / \mathrm{m}^{3}, \mathrm{E}_{1}=\mathrm{E}_{3}=16 \cdot 10^{9} \mathrm{~N} / \mathrm{m}^{2}, h_{1}=0,1-1,0 \mathrm{~m}, h_{3}=$ $\left.0,1 \mathrm{~m} ; \rho_{\mathrm{c}}=2500 \mathrm{~kg} / \mathrm{m}^{3}, \mathrm{E}_{\mathrm{c}}=25 \cdot 10^{9} \mathrm{~N} / \mathrm{m}^{2}, h_{\mathrm{c}}=0,3-0,5 \mathrm{~m}\right)$

gram in Fig 2. That is due to the reciprocity relation mentioned by Kihlman T. [3] as:

$$
\gamma_{i j} / \gamma_{j i}=\sqrt{f_{c, j} / f_{c, i}} \text {. }
$$

The influence of alternation of plate's material properties on vibration transmission coefficient was also investigated for the in-line joint. Therefore it was assumed, that all plates had been made from the same cross-section height $h_{1}=h_{3}=0,1 \mathrm{~m}$. The first plate was considered to be made of silicate bricks with the following characteristics: $\rho=2000 \mathrm{~kg} / \mathrm{m}^{3}, E=16 \cdot 10^{9} \mathrm{~N} / \mathrm{m}^{2}$. The third plate was considered to be made from different building materials with the following characteristics [17]: timber $\left(\rho=480 \mathrm{~kg} / \mathrm{m}^{3}, E=9 \cdot 10^{9} \mathrm{~N} / \mathrm{m}^{2}\right)$, plasterboard $\left(\rho=880 \mathrm{~kg} / \mathrm{m}^{3}, E=16 \cdot 10^{9} \mathrm{~N} / \mathrm{m}^{2}\right)$, silicate bricks $(\rho=$ $\left.2000 \mathrm{~kg} / \mathrm{m}^{3}, E=16 \cdot 10^{9} \mathrm{~N} / \mathrm{m}^{2}\right)$, dense concrete $(\rho=$ $\left.2500 \mathrm{~kg} / \mathrm{m}^{3}, \mathrm{E}=25 \cdot 10^{9} \mathrm{~N} / \mathrm{m}^{2}\right)$, glass $\left(\rho=2600 \mathrm{~kg} / \mathrm{m}^{3}\right.$, $\left.\mathrm{E}=70 \cdot 10^{9} \mathrm{~N} / \mathrm{m}^{2}\right)$ and steel $\left(\rho=7850 \mathrm{~kg} / \mathrm{m}^{3}\right.$, $\left.\mathrm{E}=210 \cdot 10^{9} \mathrm{~N} / \mathrm{m}^{2}\right)$. There is no much authoritative information about Poisson's ratio for common building materials in references. Therefore mostly the constant Poisson's ratio values were used, for building materials assuming $\mu=0,2-0,3$. These minor errors in Poisson's ratio are rarely important for calculating results. In theoretical case the ratio of the first and third plate density $\rho_{1} / \rho_{3}$ increases from 0,24 (the third plate from timber) to 3,93 (the third one of steel). The results showed that the change of transmission coefficient is very small due to the alternation of a plate's material properties for this kind of joint (maximum $0,3 \mathrm{~dB}$ ).

Configuration for the $\mathrm{L}$ joint is shown in Fig 1 neglecting the third and fourth plates and respectively the non-acting forces and moments. Vibration transmission coefficient $\gamma_{12}$ was calculated by Eqs $(18,20-21)$. The influence of cross-section height $h_{1} / h_{2}$ alternation on vibration transmission coefficient was investigated. Other conditions were assumed the same as for the in-line joint.

Transmission losses for the L joint, where the crosssection height of the first plate alternates from $0,1 \mathrm{~m}$ to $1,0 \mathrm{~m}$ and the cross-section height of the second plate is 


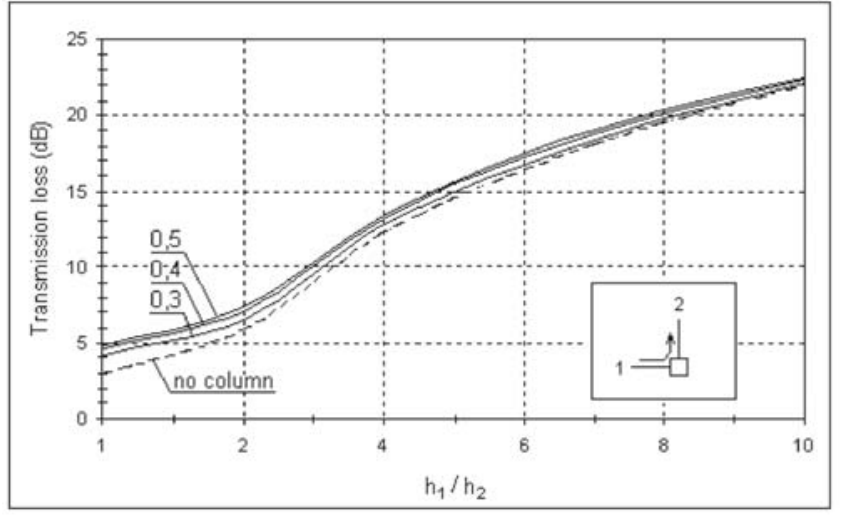

Fig 3. Transmission losses for the $\mathrm{L}$ joint $\left(\rho_{1}=\rho_{2}=\right.$ $2000 \mathrm{~kg} / \mathrm{m}^{3}, \mathrm{E}_{1}=\mathrm{E}_{2}=16 \cdot 10^{9} \mathrm{~N} / \mathrm{m}^{2}, h_{1}=0,1-1,0 \mathrm{~m}, h_{2}=$ $\left.0,1 \mathrm{~m} ; \rho_{\mathrm{c}}=2500 \mathrm{~kg} / \mathrm{m}^{3}, \mathrm{E}_{\mathrm{c}}=25 \cdot 10^{9} \mathrm{~N} / \mathrm{m}^{2}, h_{\mathrm{c}}=0,3-0,5 \mathrm{~m}\right)$

constant and equal to $0,1 \mathrm{~m}$, are shown in Fig 3. The results in the diagram are compared with the results of similar L junction without a column. For this joint the reciprocity relation is also valid. Therefore, the transmission losses, when the cross-section height of the second plate alternates and the cross-section height of the first plate is constant, will be similar to the shown in Fig 3.

The $\mathrm{T}$ joint model is shown in Fig 1 neglecting the fourth plate and respectively the non-acting forces and moments. Vibration transmission coefficients $\gamma_{12}$ and $\gamma_{13}$ were calculated by Eqs $(17-18,20-21)$. The influence of cross-section height $h_{1} / h_{2}$ and $h_{1} / h_{3}$ alternation on vibration transmission coefficient was calculated. Other conditions were assumed the same as for the mentioned joints. Transmission losses for the $\mathrm{T}$ joint, where the cross-section height of the first plate alternates from $0,1 \mathrm{~m}$ to $1,0 \mathrm{~m}$ and the cross-section height of the second plate is constant and equal to $0,1 \mathrm{~m}$, are shown in Fig 4 .

Transmission loss for the $\mathrm{T}$ joint, where crosssection height of the first plate alternates from $0,1 \mathrm{~m}$ to $1,0 \mathrm{~m}$ and cross-section height of the third plate is constant and equals $0,1 \mathrm{~m}$, are shown in Fig 5.

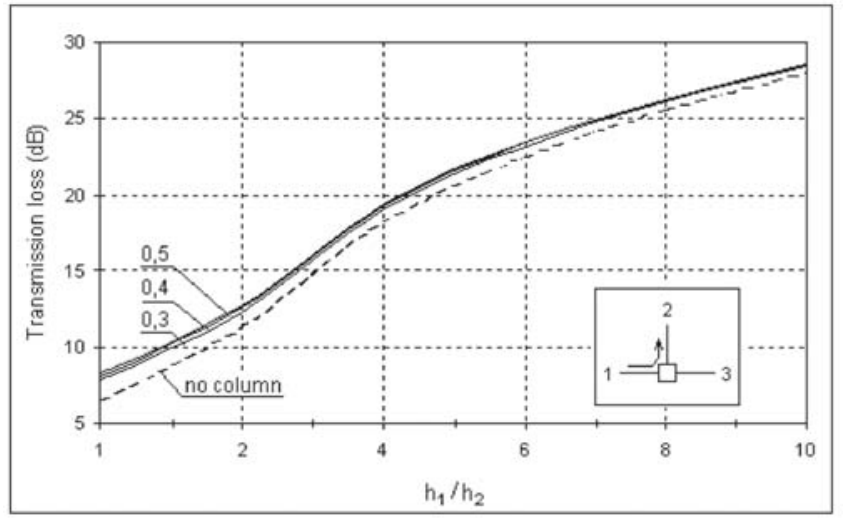

Fig 4. Transmission losses for the $\mathrm{T}$ joint $\left(\rho_{1}=\rho_{2}=\right.$ $2000 \mathrm{~kg} / \mathrm{m}^{3}, \mathrm{E}_{1}=\mathrm{E}_{2}=16 \cdot 10^{9} \mathrm{~N} / \mathrm{m}^{2}, h_{1}=0,1-1,0 \mathrm{~m}, h_{2}=0,1 \mathrm{~m}$; $\left.\rho_{\mathrm{c}}=2500 \mathrm{~kg} / \mathrm{m}^{3}, \mathrm{E}_{\mathrm{c}}=25 \cdot 10^{9} \mathrm{~N} / \mathrm{m}^{2}, h_{\mathrm{c}}=0,3-0,5 \mathrm{~m}\right)$

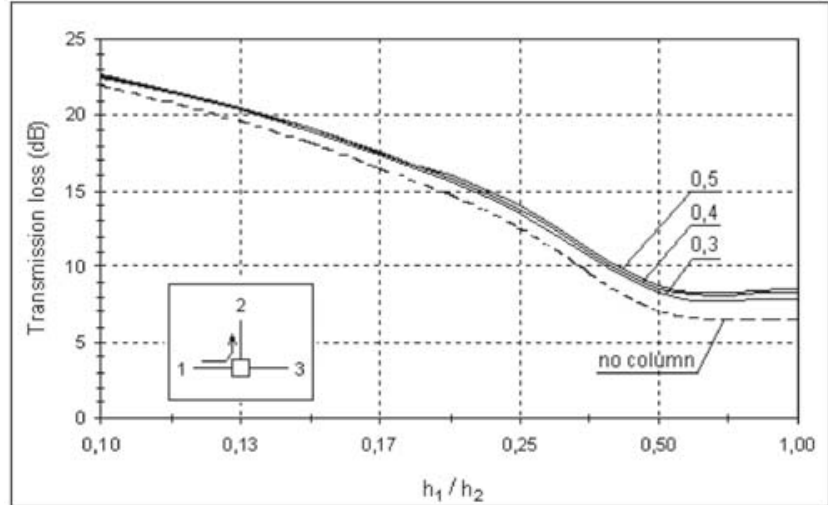

Fig 5. Transmission losses for the $\mathrm{T}$ joint $\left(\rho_{1}=\rho_{3}=\right.$ $2000 \mathrm{~kg} / \mathrm{m}^{3}, \mathrm{E}_{1}=\mathrm{E}_{3}=16 \cdot 10^{9} \mathrm{~N} / \mathrm{m}^{2}, h_{1}=0,1-1,0 \mathrm{~m}, h_{3}=$ $\left.0,1 \mathrm{~m} ; \rho_{\mathrm{c}}=2500 \mathrm{~kg} / \mathrm{m}^{3}, \mathrm{E}_{\mathrm{c}}=25 \cdot 10^{9} \mathrm{~N} / \mathrm{m}^{2}, h_{\mathrm{c}}=0,3-0,5 \mathrm{~m}\right)$

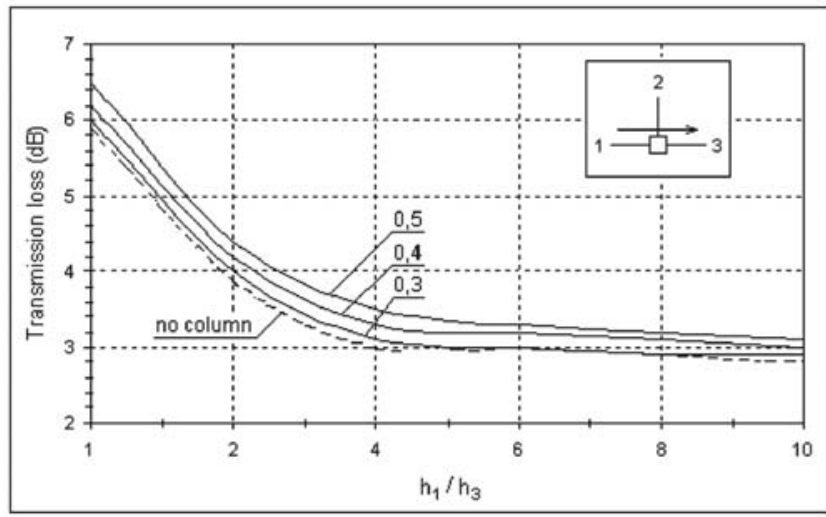

Fig 6. Transmission losses for the $\mathrm{T}$ joint $\left(\rho_{1}=\rho_{2}=\right.$ $2000 \mathrm{~kg} / \mathrm{m}^{3}, \mathrm{E}_{1}=\mathrm{E}_{2}=16 \cdot 10^{9} \mathrm{~N} / \mathrm{m}^{2}, h_{1}=0,1 \mathrm{~m}, h_{2}=0,1-$ $\left.1,0 \mathrm{~m} ; \rho_{\mathrm{c}}=2500 \mathrm{~kg} / \mathrm{m}^{3}, \mathrm{E}_{\mathrm{c}}=25 \cdot 10^{9} \mathrm{~N} / \mathrm{m}^{2}, h_{\mathrm{c}}=0,3-0,5 \mathrm{~m}\right)$

But the reciprocity relation (22) for the T-junctions is not valid. When the cross-section height of the second element alternates from $0,1 \mathrm{~m}$ to $1,0 \mathrm{~m}$, and the crosssection height of the first plate is constant, transmission losses increase more slowly than if vibration generates in a reverse direction. These results are shown in Fig 6.

Similar results are shown in Fig 7, where transmis-

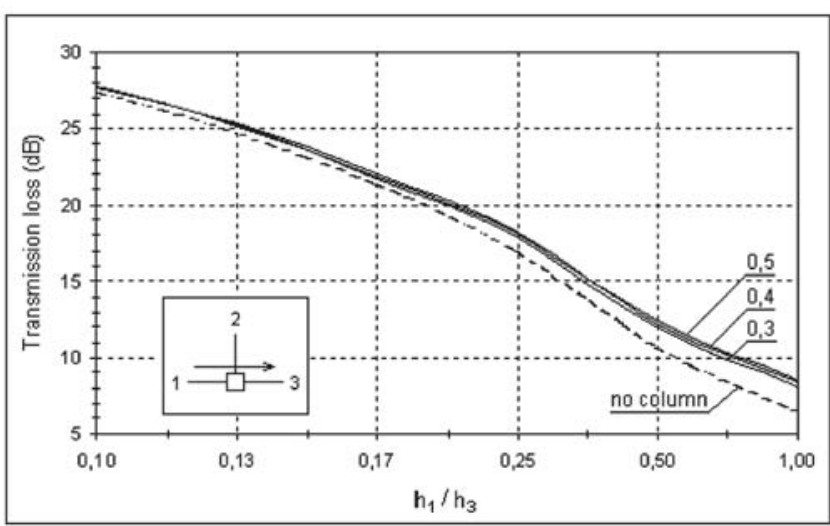

Fig 7. Transmission losses for the $\mathrm{T}$ joint $\left(\rho_{1}=\rho_{3}=\right.$ $2000 \mathrm{~kg} / \mathrm{m}^{3} ; \mathrm{E}_{1}=\mathrm{E}_{3}=16 \cdot 10^{9} \mathrm{~N} / \mathrm{m}^{2} ; h_{1}=0,1 \mathrm{~m} ; h_{3}=0,1-$ $\left.1,0 \mathrm{~m} ; \rho_{\mathrm{c}}=2500 \mathrm{~kg} / \mathrm{m}^{3}, \mathrm{E}_{\mathrm{c}}=25 \cdot 10^{9} \mathrm{~N} / \mathrm{m}^{2}, h_{\mathrm{c}}=0,3-0,5 \mathrm{~m}\right)$ 
sion losses increase more rapidly than if vibration generates in a reverse direction. There the transmission losses for the $\mathrm{T}$ joint are shown, when the cross-section height of the third element alternates from $0,1 \mathrm{~m}$ to $1,0 \mathrm{~m}$, and the cross-section height of the first plate is constant. However, the validity of the reciprocity relation is not dependent on the column influence.

Comparison of the received results with the results of similar junctions without columns [17] has shown that evaluation of the column in the junction increases vibration transmission loss.

\section{Conclusions}

The model for the bending wave transmission through the junction of walls and the column has been described. Calculations of vibration transmission through different plate-beam-plate joints have been performed. Analysing the influence of various properties of walls and the column on the vibration transmission loss it has been found that:

1. Bending wave transmission loss is the highest (about 2,6 dB), when the cross-section height of walls is constant.

2. Increasing the difference between the cross-section heights of walls, transmission loss decreases to the minimum (about 0,2 dB).

3 . Increasing the height/thickness of the column, transmission loss slightly increases.

Generally, evaluation of the column in the joint has no important influence on the vibration transmission loss. However, for accurate prediction of the structure-borne sound transmission in buildings, the influence of the column must be evaluated.

\section{References}

1. LST EN 12354:2000. Building Acoustics - Estimation the acoustical performance of buildings from the performance of the elements.

2. Cremer, L.; Heckl, M. and Ungar, E. E. Structure borne sound. Berlin: Springer Verlag, 1990. 573 p.

3. Kihlman, T. Transmission of structure-borne sound in buildings. Report 9, Stockholm: National Swedish Institute for Building Research, 1967. 64 p.

4. Woehle, W.; Beckmann, T. and Schreckenbach, H. Coupling loss factors for statistical energy analysis of sound transmission at rectangular structural slab joints. Part 1.
The Journal of Sound and Vibration, 1981, Vol 77(3), p. 323-334.

5. Woehle, W.; Beckmann, T. and Schreckenbach, H. Coupling loss factors for statistical energy analysis of sound transmission at rectangular structural slab joints. Part 2. The Journal of Sound and Vibration, 1981, Vol 77(3), p. 335-344.

6. Gibbs, B. M. Mode coupling and energy partition of sound in a system of plate junctions. The Journal of Sound and Vibration, 1986, Vol 104(1), p. 127-136.

7. Langley, R. S. and Heron, K. H. Elastic wave transmission through plate/beam junctions. The Journal of Sound and Vibration, 1990, Vol 143(2), p. 241-253.

8. McCollum, M. C. and Cuschieri, J. M. Bending and inplane wave transmission in thick connected plates using statistical energy analysis. Journal of Acoustical Society of America, 1990, Vol 88(3), p. 1480-1495.

9. Walsh, S. J. and White, R. G. Vibrational power transmission in curved beams. The Journal of Sound and Vibration, Vol 233(3), 2000, p. 455-488.

10. Lase Y., Ichchou, M. N. and Jezequel, L. Energy flow analysis of bars and beams: theoretical formulations. The Journal of Sound and Vibration, Vol 192(1), 1996, p. 281-305.

11. Craven, P. G. and Gibbs, B. M. Sound transmission and mode coupling at junctions of thin plates. Part I: representation of problem. The Journal of Sound and Vibration, 1981, Vol 77, p. 417-427.

12. Craven, P. G. and Gibbs, B. M. Sound transmission and mode coupling at junctions of thin plates. Part II: parametric survey. The Journal of Sound and Vibration, 1981, Vol 77, p. 429-435.

13. Gibbs, B. M. and Gilford, L. S. The use of power flow methods for the assessment of sound transmission in building structures. The Journal of Sound and Vibration, 1976, Vol 49(2), p. 267-286.

14. Steel, J.A. Sound transmission between plates in framed structures. The Journal of Sound and Vibration, 1994, Vol 178(3), p. 379-394.

15. Stauskis, V. J. and Mickaitis, M. Vibration attenuation at asymmetric cross-form joints of buildings. Journal of Civil Engineering and Management, Vol 11, No 2. Vilnius: Technika, 2005, p. 129-135.

16. Stauskis, V. J. and Mickaitis, M. Estimation of vibration transmission coefficient at asymmetric junctions of buildings. In: Abstracts of 8 th International conference "Modern building materials, structures and techniques", May 19-21, 2004. Vilnius: Technika, 2004, p. 297-298.

17. Craik, R. J. M. Sound transmission through buildings using statistical energy analysis. UK: Gower, Aldershot, Hampshire, 1996. 261 p.

\section{VIBRACIJŲ SKLIDIMAS KARKASINIŲ PASTATU SIENŲ IR KOLONOS MAZGUOSE}

\section{Mickaitis, V. J. Stauskis}

Santrauka

Statybos praktika parodè, jog struktūrinio-orinio garso sklidimas pro mazgus dažniausiai būna veiksnys, galintis labai sumažinti orinio garso izoliaciją pastatuose. Projektiniais skaičiavimais jis nustatomas pagal vibracijų perdavimo koeficientą. Analizuojamas garso sklidimas pro karkasinio pastato mazgus. Patalpos pastatuose yra formuojamos iš sienų ir perdangų, 
kurios jungiasi prie kolonų. Pastato plane prie kolonos gali būti prijungta keletas sienų, taip suformuojant ịvairių formų mazgus. Tokie mazgai modeliuojami kaip idealizuotos plokštės-strypo-plokštès jungtys. Tiriant garso sklidimą pro tokius mazgus, reikia ịvertinti ir kolonos ịtaką. Darbo tikslas yra nustatyti, kokią įtaką ịvairūs sienų ir kolonos parametrai turi garso sklidimui pastatuose pro mazgus. Rezultatai lyginami su analogiškų mazgų be kolonos tyrimų rezultatais.

Raktažodžiai: struktūrinè akustika, vibracijos, struktūrinis-orinis triukšmas, perdavimo nuostoliai.

Marius MICKAITIS. MSc, PhD student at the Dept of Building Construction, Vilnius Gediminas Technical University, Lithuania. Member of LSIS (Lithuanian Society of Building Engineers). Research interests: building acoustics, sound energy transmission through junctions in buildings.

Vytautas J. STAUSKIS. Prof Dr Habil, Head of Dept of Building Construction and Building Physics Scientific Laboratory, Vilnius Gediminas Technical University, Lithuania. Author of more than 130 scientific articles, also a monograph and textbooks. He made 9 inventions in the field of architectural acoustics. International category scientific expert of European Acoustics Association. Chairman of Audio Engineering Society Dept in Lithuania. Foreign member of International Acoustics and Vibration Science Institute. Foreign member of France Acoustics Association. One of the National Science Awards winners. Research interests: architectural acoustics, acoustical properties of multipurpose halls, building acoustics. 